\title{
日本におけるアロマンティック／アセクシュアル・ スペクトラムの人口学的多様性
}

一「Aro/Ace 調査2020」の分析結果から ${ }^{1)}$ -

\section{三宅大二郎 ${ }^{\mathrm{i})}$ ・平森大規 ${ }^{\mathrm{ii}}$}

\begin{abstract}
欧米諸国では，無作為抽出調查や当事者調査を用いた研究によりアセクシュアル人口の規模やそ の多様性が明らかになりつつある。一方, 日本では無作為抽出調查を用いた研究が少数あるのみで, アセクシュアル人口の詳細な実態は検討されていない。そこで本論文では, Aro/Ace 調査実行委 員会が実施したウェブ調查「アロマンティック/アセクシュアル・スペクトラム調查2020」を分析 した，回答者はシスジェンダー女性，若年層，南関東居住者が多い傾向であった，アロマンティッ クとアセクシュアルを自認する人が多かったが，他のAro/Ace アイデンティティを自認している 人も確認された。日本独自の区分である「ノンセクシュアル」の分析も行った。自慰行為と性欲に ついてはアセクシュアルでも一定数みられたのに対し, 他者と性行為をしょうと思う割合は特にア セクシュアルで少なかった。他者との性行為が自認に重要な意味を持つことが示唆された。
\end{abstract}

キーワード：アセクシュアル，アロマンティック，LGBT, 性的マイノリティ, 性的指向・恋愛的 指向

\section{I 。はじめに}

近年，レズビアン，ゲイ，バイセクシュアル，トランスジェンダー（LGBT）を含む性 的マイノリティの可視化とともに，性的指向におけるマイノリティの 1 グループとして 「他者に性的に惹かれないこと」（デッカー 2019：20）を意味する「アセクシュアル／ア セクシュアリティ (asexual/asexuality) ${ }^{2)} 」$ が日本においても雑誌記事やウェブニュー スなどを通して少しずつ社会に認知され（例えば，大川 2018，山本 2018），学術的にも 注目を集めはじめている（例えば, 松浦 2020, 吉岡 2019)。諸外国では, 人口学の領域

i）中央大学ダイバーシティセンター嘱託職員

ii）ワシントン大学大学院社会学研究科 (Department of Sociology, University of Washington)

1）本研究は, JSPS 科研費 JP16H03709「性的指向と性自認の人口学一日本における研究基盤の構築」の助成 を受け，科研プロジェクトの研究として行ったものである。「アロマンティック／アセクシュアル・スペクト ラム調査2020」データの二次利用にあたっては, Aro/Ace 調査実行委員会の許可を得た. 英文要旨の作成に あたっては, カリフォルニア州立大学サンバーナーディノ校社会学部の Megan Carroll 氏による助言を受け た。 ここに記して感謝申し上げたい.

2）セクシュアル（sexual）に否定を表す接頭辞「a」が付いた言葉である. 英語圈では「a」を「エィ」と発 音することが多い一方, 日本では「ア」と発音されることが多く,「アセクシュアル」と表記することが多い. しかし, 日本でも「エィセクシュアル」と発音されることがある。その他，「A セクシュアル」という表記も ある。 
でも『セクシュアリティ人口学に関する国際ハンドブック (International Handbook on the Demography of Sexuality)』(Baumle ed. 2013) において「アセクシュアリティ の人口学 (The Demography of Asexuality)」(Bogaert 2013) という章が設けられる など，アセクシュアル人口を対象とする研究が数少ないものの蓄積されつつある。また， 社会学をはじめとする隣接領域では, アセクシュアルの回答者数が少なくなりがちな無作 為抽出調査のみならず，アセクシュアルを主な対象とするアセクシュアル当事者団体によ るオープン型ウェブ調査を利用した分析も行われている（Carroll 2020）。日本に目を向 けると，大阪市（釜野他 2019） や埼玉県（埼玉県 2021）における代表性のある無作為抽 出調査でアセクシュアルを選択肢の 1 つとして含んだ性的指向の設問がたずねられており, アセクシュアルを分析の射程に含んだ人口学研究も行われている (Hiramori and Kamano 2020a, 2020b).

しかしながら，これらの研究はアセクシュアルに関する貴重な人口学研究である一方で, 2 つの欠点を抱えている. 1つ目の欠点は, 大半の研究がイギリスやアメリカをはじめと する欧米諸国を対象とした研究であることである（ただし，上記で挙げた日本における研 究以外にも中国を対象とした研究 (Zheng and Su 2018) など，少数ながら例外もある). 後述するように，そもそも「アセクシュアル」の意味が日本語と英語で異なる場合がある など，アセクシュアルをとりまく社会的・文化的背景は日本と英語圈で大きく異なる。し たがって，欧米社会を対象とした研究における知見を日本社会にそのままあてはめること は必ずしもできない可能性が高い，2つ目の欠点は，Hiramori and Kamano (2020a, 2020b）で示されているような出生時に割り当てられた性別（以下，出生時性別）や年齢 階級別にみたアセクシュアルの分布をはじめとする基礎的な人口学的特徴以外については, 日本におけるアセクシュアル人口の詳細な実態が把握できていないことである. 日本で行 われている数少ないアセクシュアリティの人口学研究では一般人口を対象とする無作為抽 出調査が用いられているため, アセクシュアルに焦点を絞った分析を行うのが調查手法上, 困難になっている.

そこで本論文では，日本において初めてアセクシュアルを主な対象としたオープン型ウェ ブ調査である「アロマンティック/アセクシュアル・スペクトラム調査2020」（以下， $\lceil$ Aro/Ace 調査2020」）を用いて（Aro/Ace 調査実行委員会 2020), 日本におけるアロマ ンティック／アセクシュアル・スペクトラムの人口学的多様性を記述する. 次章では, 第 1 にアセクシュアルの概念的側面について検討し, アセクシュアルや関連する概念の整理 をするとともに，アセクシュアルをとりまく日本特有の文脈についても解説する. 第 2 に, 人口学領域を中心にこれまで行われてきたアセクシュアルに関する研究動向を概観し，日 本におけるアセクシュアル研究の課題を指摘する. 


\section{II . 背景}

\section{1. アセクシュアルに関連する概念}

(1) アセクシュアルの定義

アセクシュアル研究において，アセクシュアルは性的惹かれ（sexual attraction）の 欠如として捉えるのが一般的である（Chasin 2011）。性的惹かれとは，他者によって性 的欲望（sexual desire）や性的興奮（sexual arousal）をかき立てられ，その人に強い関 心を抱くことである（Mardell 2016）。なお，性的惹かれは性的欲望や性行動，身体的な 興奮, 恋愛感情（romantic inclination）から独立した別の要素であり（Bogaert 2015), 性的欲望や性行動などその他の要素を必ずしも伴うものではないという点に留意する必要 がある。

一方で，アセクシュアルは性的欲望の障害など性機能不全として捉えられ病理化され た上で，医学的研究の対象にもされてきた（Scherrer 2008）。例えば，アメリカ精神 医学会が発行する「精神疾患の診断・統計マニュアル第 4 版 (DSM-IV)」は，苦痛 （distress）や対人関係の困難を伴う性的欲望の欠如を「性的欲望低下障害（Hypoactive Sexual Desire Disorder, HSDD)」と定義している（American Psychiatric Association 2000).ブレイン（2006：35）によると，「精神分析ではセクシュアリティを主観性を形成 する中心的な力であると見なすが，この立場からするとアセクシュアリティは抑压や生化 学や器官の「異常」にその原因があると説明される」3).アセクシュアルは「性的に惹か れないこと」であり，性的欲望の欠如によって診断される HSDD とは区別されるという 見方がある一方で（Bogaert 2006），性的惹かれと性的欲望によってアセクシュアルと HSDD を区別することは混乱を呼ぶとも指摘されている（Chasin 2014）。実際に，アセ クシュアルを自認する人は他のセクシュアリティの人と比べて性的欲望が低いと報告され ており（Prause and Graham 2007），アセクシュアルを自認する人が HSDD と診断され る可能性は否定できない. Hinderliter（2013）はアセクシュアルと HSDD の区別につい て，定義以上に各概念の歴史とその目的に注目すべきであると述べ，アセクシュアルは当 事者が共通の経験をもとにコミュニティをつくるための概念である一方，HSDD は医療 者が問題を描き出し，治療するために構築された概念であると指摘している。これはアセ クシュアルを自認する人が HSDD と診断された場合，治療という形で自身のあり方に介 入される可能性を示唆している. DSM-IV の改訂版である DSM-5 では，アセクシュアル を自認する人には性的欲望の障害 ${ }^{4)}$ の診断を下さないという基準が追加されたため (American Psychiatric Association 2013)，アセクシュアルを性的欲望の障害と捉える

3）フロイトによる精神分析理論をアセクシュアル研究の観点から批判的に考察した論考として松浦（2020）が ある.

4）HSDD はDSM-5 で「男性の性的欲望低下障害（Male Hypoactive Sexual Desire Disorder）」と「女性の 性的関心・興奮障害（Female Sexual Interest/Arousal Disorder）」に変更された。これは性的欲望と興奮 の困難さが，女性の場合はしばしば同時に起こり，男性では別々に起こることを考慮した結果だと説明されて いる (American Psychiatric Association 2013). 
見方は一般的ではなくなるかもしれない。しかし，性機能不全とセクシュアリティにおけ る「通常のバリエーション（normal variation）」の区別にはあいまいさが依然として残 り（Hinderliter 2015), アセクシュアルの病理化は今後も注視すべき論点である。そし てこれは現代の欧米社会において人々は性的であるべきである，または性的なことが健康 であるという前提と関連しており（Gazzola and Morrison 2011）, 欧米社会以外の文脈 において性的であることが健康や病理といかに関連付けられているかを検討する必要性を 示唆している.

その一方で，このように性的惹かれや性的欲望の欠如が否定的に捉えられるようになっ たのは比較的最近のことであり，それまでは多くの宗教でむしろ肯定的に捉えられてきた といわれている（Bogaert 2006）。現代においても，例えばキリスト教のコミュニティで は性的でないことが推奨され，アセクシュアルであることは問題とならないら ことが多い (Tori 2018). このようなアセクシュアルと宗教的価值観との親和性が, 以下のような混 同を生むことがある.エヴァンズ（2006）によれば，セリバシー（celibacy）は「性的関 係を持たないこと」，貞節の純潔さを表し，さまざまな理由で禁欲することであるが，そ のセリバシーが（誤って）アセクシュアリティを意味する言葉として用いられるという.

つまり，アセクシュアルであることが，宗教的な理由などで禁欲していることだと䛊解さ れることがある。しかしながら，アセクシュアルの文脈ではセリバシーは明確に区別され ており，アセクシュアルは本人の意思によって「性的関係を持たないこと」や禁欲するこ とではないとされている (Hinderliter 2013). 以上の議論から，アセクシュアルを性的 欲望や性行動の欠如ではなく, 性的惹かれの欠如として捉えることがより適切であると推 察される.

アセクシュアルを定義する上で, 性的惹かれに加えてもう 1 つの重要な論点としてアセ クシュアルの自認（アイデンティティ）が挙げられる. 2000年前後から性的指向の 1 つ して概念化されたアセクシュアルはアイデンティティとして，そして 1 つのムーブメント として表出したため (Hinderliter 2013)，近年の研究はアセクシュアルを性的指向の 1 つ，ないしはその欠如として捉えてきた（Chasin 2011）。アセクシュアルが性的指向の カテゴリーとして理解されることは，レズビアンやゲイなど他のカテゴリーと同様に，あ る人々がアセクシュアルという自認を持っていると研究者が推定するようになることを意 味する (Chasin 2011). アセクシュアル自認をどのように把握するかについては調査に よりさまざまな手法があるが (Brotto et al. 2010, Greaves et al. 2017, Prause and Graham 2007), アセクシュアルを定義する手法の 1 つとして, 性的惹かれの他にアセク シュアルの自認が用いられていることがわかる。

しかしながら，性的惹かれや自認のみをもとにアセクシュアルであるか否かを測定する ことの妥当性に関しては，しばしば議論の対象となってきた．例えば，アセクシュアルと 自認している人のみを対象にすることで, 自認していないアセクシュアルな人の存在を隠

5）キリスト教のコミュニティにおいても，結婚をすることや子を産み育てることが期待される点で必ずしもア セクシュアルが肯定されているとは言えない点に留意する必要がある（Tori 2018）. 
し，アセクシュアルに関する理解を偏らせるという指摘（Brotto and Yule 2011）や， 性的惹かれや自認など性的指向に関するさまざまな質問を問うと回答が一致しないなど性 的指向のあり方は多面的であるという指摘 (Brotto et al. 2010, Prause and Graham 2007）がある。このような指摘に呼応して，Chasin（2011）は，ある個人がアセクシュ アルであるか否かを性的惹かれや自認に関する設問を用いて一義的に測定できるという発 想は，アセクシュアルが性的指向に基づく同質性の高い集団であるという捉え方を前提に していると主張する. Chasin（2011）によると，アセクシュアルは惹かれや欲望の有無， 程度，質などの要素で構成されている複雑な現象であり，単に「性的に惹かれることがな い」というわけではない.アセクシュアルの意味は自認している各人により異なり，性的 惹かれだけではなく性的欲望や性行動によって自認することもあるという Scherrer （2008）の調査結果は，この主張を裏付けるものである。したがって，アセクシュアルと いう自認には多義性があり，アセクシュアルを自認することが，そのままある特定の性質 を表すわけではないということが示唆される.

それでは，性的惹かれ，性的欲望や性行動に関して多様な人々がアセクシュアルという 共通の自認を持つのはなぜなのだろうか. Chasin（2014）によると，アセクシュアルと はある特定の性質を表すカテゴリーではなく，社会における強制的性愛（compulsory sexuality）の可視化に有用な政治的な性的指向カテゴリー（political sexual orientation category）である。強制的性愛とは，性行為やセクシュアリティを特別なものであると 位置づけ, 身体の健康や自己形成, 親密な関係と紐づける考え方や規範である（Przybylo 2016).すなわち，アセクシュアルという自認を持つことで，この規範を可視化させ，相 対化させるのに寄与することが可能になると考えられる. セクシュアリティは生得的, 本 質的なものであると捉えることでアイデンティティを正当化しやすくなると言われている が (Scherrer 2008)，この傾向がアセクシュアルを自認する人々にもあると指摘されて いる (Pacho 2013). 加えて，アセクシュアルとしてのアイデンティティ形成がアセクシュ アル当事者のコミュニティ形成にも貢献している点など，他の周縁化された性的指向に関 わるアイデンティティを持つ集団と類似の社会心理的プロセスがアセクシュアルにもみら れる (Scherrer 2008).さらに，アイデンティティ形成の機能の一例として，アセクシュ アルを性的指向の 1 つとして位置づけることで，他の非異性愛の性的指向と同じように人々 にアセクシュアルを理解し，尊重し，病理として扱わず，性的指向を変えようとしないよ う促す働きが挙げられる (Hinderliter 2013)。これらの議論はアセクシュアル概念の意 味内容だけでなく，アセクシュアルというアイデンティティが持つ機能について検討する 必要性を認識させる。

自認と同様に性的惹かれについても，それをもとにアセクシュアルであるか否かを判断 することの妥当性を問う議論がある一方で, 性的惹かれという概念の有用性も指摘されて いる。アセクシュアルの中心的要素と捉えられてきた性的惹かれ概念は，自慰行為など性 的とされることも多い行動をする個人を包括し（当事者コミュニティにおいて自慰行為は 「他者に向かない性欲（undirected sex drives）」として概念化され，アセクシュアルと矛 
盾しないとされる), 性行動を基準とする考え方（セリバシーとの混同，性行為をするア セクシュアルを排除すべきとする立場）と距離を取ることが可能になる点で有用性がある (Hinderliter 2013). 性的に惹かれたことがない人は，経験したことのない性的惹かれに ついてたずねられても理解できないはずであり, その点で定義として矛盾があるという指 摘（Hinderliter 2009）も，上述の有用性ならびに，アセクシュアルというアイデンティ ティの多義性と機能を鑑みれば，定義として不適切であるとまでは言えないのかもしれな い.これらから，アセクシュアルにはさまざまな定義の仕方があり，人口学研究において アセクシュアルか否かをどのような指標を用いて測定するかについては, 研究目的との整 合性を踏まえた上で慎重に検討する必要があることがわかった。

(2) アセクシュアルに関連する概念と当事者の多様性

本項では，アイデンティティを共有する当事者コミュニティで用いられる概念を整理す る. 特に, アセクシュアルのコミュニティで性的次元と恋愛的次元が区別される傾向につ いて記述し，当事者の多様性について述べ.

当事者コミュニティとして最も有名なのは，2001年に設立された Asexual Visibility and Education Network（AVEN $)^{6)}$ である. 当事者を対象にした数多くの調査（例えば, Bogaert 2012, Brotto et al. 2010, Brotto and Yule 2011, Prause and Graham 2007, Scherrer 2008, Yule et al. 2014）が AVEN のサイトを通して協力者を集めている. AVEN はアセクシュアルのコミュニティがそのニーズや経験において非常に多様性があ ると述べており ${ }^{7)}$ ，その多様性についてはコミュニティ内で用いられるアセクシュアル以 外のアイデンティティ・カテゴリーの多さからもうかがうことができる。例えば，「グレ イアセクシュアル/グレイセクシュアル (gray-asexual/gray-sexual)」および「デミセ クシュアル (demisexual)」はその代表例である．前者は「アセクシュアルとセクシュア ルの間のある位置で自認している人」 ${ }^{8)}$ ，後者は「情緒的な繋がりができてからのみ性的 惹かれを感じる人」 ${ }^{9)}$ という意味で用いられる。なお，前者のようなカテゴリーが成立す るのは，アセクシュアル・コミュニティにおいてアセクシュアルとセクシュアルが連続し ていると考える「性的指向の連続スペクトラムモデル (the continuous spectrum models of sexual orientation)」が採用されているためである (Chasin 2011). その他，「性的 な感情を返されることや他者との行為を必要としない形で性的に惹かれる」という意味の 「リスセクシュアル (lithsexual) 」10) など，アセクシュアルのコミュニティには実に様々 なアイデンティティのラベルが存在する.

さらに，コミュニティ内で頻繁に語られる重要な概念として「アロマンティック

6) https://www.asexuality.org/（2021年 2 月25日最終アクセス）

AVEN はアセクシュアルを「性的惹かれを経験しない人 (a person who does not experience sexual attraction)」と定義する.

7）https://www.asexuality.org/?q=overview.html（2021年 2 月25日最終アクセス）

8）http://wiki.asexuality.org/Gray-A/Grey-A（2021年 2 月25日最終アクセス）

9) http://wiki.asexuality.org/Demisexual（2021年 2 月25日最終アクセス）

10）https://rainbowpedia.wikia.org/wiki/Lithsexuality（2021年 2 月25日最終アクセス） 
(aromantic)」が挙げられる.アロマンティックは「恋愛的に惹かれない，またはほと んど惹かれない」11) という意味で，「恋愛的指向 (romantic orientation)」の 1 つさされ， 性的指向の 1 つとされるアセクシュアルとは別次元の概念として紹介される．恋愛的指向 とは恋愛的に惹かれることの有無や対象の性別に関する概念であり（Antonsen et al. 2020)，アセクシュアルの性的指向に関する議論の中で性的指向と恋愛的指向が区別され るようになったと言われている（Chu 2014）。アセクシュアルを自認する人の中には， 「ヘテロロマンティック (heteroromantic)」, 「ホモロマンティック (homoromantic) 」, 「バイロマンティック (biromantic)」などアロマンティック以外のカテゴリーを自認す る例も報告されており（Brotto et al. 2010），アセクシュアルの恋愛的指向の多様性が 示唆される。なお，恋愛的に惹かれる性別の差異は問わず，恋愛的に惹かれるアセクシュ アルをまとめて表現する際は「ロマンティック・アセクシュアル (romantic asexual)」 と呼ぶ. 上記カテゴリーが，それぞれへテロセクシュアル，ホモセクシュアル，バイセク シュアルと対応しているように，「グレイアロマンティック／グレイロマンティック (gray-aromantic/gray-romantic)」や「デミロマンティック (demiromantic)」,「リス ロマンティック (lithromantic) 」12) というカテゴリーも存在する。惹かれる対象の性別や, その有無，惹かれの仕方を表す接頭辞（hetero-, homo-, bi-, a-, gray-, demi-）と惹か れの種類を表す接尾辞（-sexual, -romantic）の組み合わせでこれらカテゴリーが構成さ れていることがわかる．上述のような性的惹かれと恋愛的惹かれを分ける考え方は，主に コミュニティ内で「スプリット・アトラクション・モデル (the split attraction model) $\rfloor^{13)}$ とも呼ばれ，この区別がコミュニティにとって重要な意味を持つことが推察される.

以上，アセクシュアル・コミュニティの多様性についてカテゴリーの細分化という側面 から検討したが，コミュニティが共同体として維持されるために必要と思われる包括概念 についても簡単に説明する。本論文では「Ace（日本でもそのままの表記が多い）」, 「Aro（日本でもそのままの表記が多い）」，「スペクトラム (spectrum)」を紹介する. Ace はアセクシュアルならびにそれに近いカテゴリーのアイデンティティ全体を指す略語 で ${ }^{14)}$ ，スペクトラムは範囲，領域を意味する。 スペクトラムそのものは英語で一般的に使 われる単語だが, アセクシュアル・コミュニティでは, あるアイデンティティの周辺／関 連という意味を持つ用語として使われる ${ }^{15)}$. 両者を組み合わせて，「アセクシュアル・ス ペクトラム, Ace スペクトラム」と呼ぶことがある。一方，アロマンティックなど恋愛的 指向に関連するアイデンティティを包括した略語としては「Aro」があり，「アロマンティッ ク・スペクトラム, Aro スペクトラム」という言葉も使われている．近年では Ace コミュ

11）http://wiki.asexuality.org/Aromantic（2021年 2 月25日最終アクセス）

ロマンティック（romantic）に否定を表す接頭辞「a」をつけた表現である，アセクシュアルと同様に，英語 圈では「エィ」と発音されることが多いものの, 日本では「ア」と発音されることが多い.

12）https://mogai.fandom.com/wiki/Lithromantic（2021年 2 月25日最終アクセス）

13）https://aroacefaq.tumblr.com/post/143810110365/the-split-attraction-model-what-is-it（2021年 2 月 25 日最終アクセス)

14）https://www.asexuality.org/?q=general.html\#def（2021年 2 月25日最終アクセス）

15）https://www.asexuality.org/?q=general.html\#def（2021年 2 月25日最終アクセス） 
ニティとは別に, Aro コミュニティも発展しつつある ${ }^{16)}$. Ace と Aro 両方のスペクトラ ムについて言及する際には，「アロマンティック／アセクシュアル・スペクトラム， Aro/Ace スペクトラム」と呼ぶこともある ${ }^{17)}$.

\section{(3) 日本の文脈}

最後に日本の当事者コミュニティについて概観する。 日本では英語圈におけるコミュニ ティの発展に伴い，2002年頃からアセクシュアルという言葉が主に性的マイノリティの間 で少しずつ認知されるようになったと言われている ${ }^{18)}$. アセクシュアルに関する情報，特 にアイデンティティ・カテゴリーなどは英語圈の概念をカタカナにして流用していること が多いが，その概念の意味内容は英語圈と異なる部分がある。例えば，日本ではアセクシュ アルを「恋愛感情がなく, 性的な欲求がない（アロマンティックのアセクシュアルに近い）」 という意味で使い, 「恋愛感情があり, 性的な欲求がない（ロマンティックのアセクシュ アルに近(）」ことを「ノンセクシュアル」と呼ぶことがある ${ }^{19)}$.これは日本独自の区分 であり，英語圈以外の諸外国でもみられない傾向である.

日本でこうした区分ができる背景としては，「恋愛感情の有無」を中心に捉える点が影 響していると言われており ${ }^{20)}$ ，これは日本社会の恋愛感情を重視する傾向が反映されてい ると考えられる。日本の量的調査において性的指向と性自認のあり方をどのようにたずね るかについて方法論的研究を行った Hiramori and Kamano（2020b）も，日本において は，個人の性的指向を測定する際に欧米諸国のような性行動，性的惹かれ，性的指向アイ デンティティなどではなく，恋愛的惹かれを用いることが多いと指摘している。な拉近年 では，日本においても英語圈に近い用法が見られ，当事者によってアセクシュアルの意味 が異なるのが日本のアロマンティック／アセクシュアル・スペクトラム・コミュニティの 現状である．本論文では，諸外国の研究との比較も鑑み，英語圈に近い用法でアセクシュ アルを使用する。

\section{2. アセクシュアルに関する人口学研究の動向}

(1) 諸外国における無作為抽出調査

近年，諸外国では無作為抽出調査において性的指向をたずねることが増えてきているが， アセクシュアル人口を把握できるようなたずね方をしている調査は数が限られている。カ リフォルニア大学ロサンゼルス校 (University of California, Los Angeles) に設置され ているウィリアムズ研究所 (Williams Institute) が招聘したセクシュアル・マイノリティ・

16）https://www.aromanticism.org/（2021年 2 月25日最終アクセス）

17）https://identitiesandorientations.weebly.com/aroace-spectrum.html（2021年 2 月25日最終アクセス）

Ace とAro を包括する概念として，A-spec という言葉もある.

18）https://www.asexual.jp/history_japan.php（2021年 2 月25日最終アクセス）

19）https://www.asexual.jp/info.php\#japan（2021年 2 月25日最終アクセス）

2003年頃には，狭義のアセクシュアル（現在のアロマンティック・アセクシュアル）と広義のアセクシュアル (恋愛的指向を問わずアセクシュアル) という分け方も確認されている.

20）https://www.asexual.jp/info.php\#japan（2021年 2 月25日最終アクセス） 
アセスメント研究チーム (Sexual Minority Assessment Research Team, SMART) （2009）による量的調査における性的指向の測定に関するベストプラクティスは，さまざ まな調査で設問ガイドラインとして広く利用されているが，性的指向アイデンティティを たずねるモデル設問の選択肢にアセクシュアルは含まれていない，また，性的惹かれにつ いても「（a）女性のみに惹かれる，（b）ほとんど女性に惹かれる，（c）男性と女性に同 じくらい惹かれる，(d）ほとんど男性に惹かれる，（e）男性のみに惹かれる，（f）わから ない」（SMART 2009: ii）という選択肢を利用することが推奨されており，他者に対す る性的惹かれを経験しない人が回答できる選択肢は存在しない.

しかしながら, 不完全な指標を用いながらむアセクシュアルの人口規模や人口学的特徴 を把握すべく，これまでいくつかの調查研究が行われてきた。とりわけ重要なのが, Bogaert（2004）によるイギリスの無作為抽出調査を利用した研究と Poston and Baumle （2010）によるアメリカの無作為抽出調査を利用した研究である. Bogaert（2004）は性 的惹かれがないことをアセクシュアルの指標とした上でイギリスに住む16歳から59歳を対 象に行われた「性に対する態度とライフスタイルに関する全国調査 (National Survey of Sexual Attitudes and Lifestyles, NATSAL-I)」を分析し，回答者のうち1.1\%がこれま で誰に対しても性的惹かれを感じたことがないアセクシュアルであると示した。また人口 学的特徴を検討した結果, アセクシュアルと分類された人はそうでない人に比べて学歴や 職業階層，非単身割合が低く，非白人および女性に多いことも明らかにした．非アセクシュ アル回答者のうち $43 \%$ が男性であるのに対し，アセクシュアル回答者では $29 \%$ が男性であっ た. Bogaert（2004）は女性の方が多い背景要因として, 男性の方が女性よりも性的に活 発であることを性役割として求められていること，男性と比べて女性の方が性器の反応か ら性的に興奮していてもそのことに気づかずに他者のことを性的な対象として捉えていな いこと，女性の方が自慰などのような性的指向を形成するにあたって重要な経験をもって いないこと，他者に対する性的惹かれをもとに性的指向を測定しても女性の主観的経験を うまくとらえることができていないことなどの可能性を指摘している，その一方で年齢に ついては，アセクシュアルは性的な経験の少ない若年層に多いだろうという予想に反し， むしろアセクシュアル回答者 (平均年齢：38歳) は非アセクシュアル回答者（平均年齢： 36歳）に比べて平均年齢が 2 歳高いことがわかった.

Poston and Baumle（2010）は，Bogaert（2004）がイギリスの調査をもとに行ったも のと類似した分析をアメリカに住む15歳から44歳を対象に2002年に実施された「家族の拡 大に関する全国調査（National Survey of Family Growth, NSFG）」を利用して行い, さらにBogaert（2004）で用いられた性的惹かれ以外にも性行動およびアイデンティティ の指標を用いてアセクシュアル人口の規模を推定した。分析の結果，女性のうち $0.8 \%$, 男性のうち0.7\%が性的惹かれについて「わからない（not sure）」と回答しており, 女性 のうち $4.8 \%$ ，男性のうち6.1\%がこれまでにセックスをしたことがないことがわかった. アイデンティティについては，女性のうち $3.8 \%$ ，男性のうち $3.9 \%$ が「その他の何か (something else)」を選択しており，女性のうち $9.2 \%$ ，男性のうち $11.9 \%$ が，性的惹か 
れ, 性行動, アイデンティティの少なくともいずれか 1 つについてアセクシュアルと分類 されうる回答をしていた。 また，これらの $9.2 \%$ の性や $11.9 \%$ 男性が必ずしも性的指 向に関する 3 つ側面すべてについてアセクシュアルと分類されるような回答を一律に行っ ているわけではないことも明らかにした。このように, Poston and Baumle (2010) は アセクシュアルをどのように定義するかによって人口規模の推定值が大きく変わることを 示した一方で, Poston and Baumle（2010）自身が指摘しているように，NSFGを利用 した分析の限界点として，性的惹かれに関して「わからない」という回答は，性的惹かれ のないアセクシュアル以外も回答する可能性があることが挙げられる。同様に，アイデン ティティに関して「その他の何か」という回答は，これ以外に選択肢として用意されてい る異性愛, 同性愛, 両性愛以外のどのアイデンティティを持つ回答者も選択する可能性が ある.したがって, これらの指標はアセクシュアル人口の規模を推定するにあたって完璧 な指標ではなく，実際のアセクシュアル人口よりも規模を大きく推定してしまう。そのた め，より正確にアセクシュアル人口をとらえ，その生活実態を理解するためには，

Hiramori and Kamano (2020b) が推奨するモデル設問のように，性的惹かれがないと いう選択肢を性的惹かれの設問に含めたり，アセクシュアルという選択肢を性的指向アイ デンティティの設問に含めたりした上で，性的惹かれやアイデンティティなど，性的指向 のどの側面に研究関心があるかを明確にすることが重要である.

(2) 当事者団体による有意抽出調査

本項では, 当事者団体による量的調査を紹介する. 当事者団体による調査は当事者コミュ ニティのネットワークを用いて関心層にアプローチするため, 無作為抽出調査では把握困 難なマイノリティ層による回答を多く得られる傾向にある。ささに，調査が当事者コミュ ニティの状況に則して設計されているため, 性的指向と恋愛的指向を区別したアイデンティ ティなど，当事者の多様性を把握しやすいという利点がある.

当事者団体による調査として大規模なものは「アセクシュアル・コミュニティ・サーベ イ (Asexual Community Survey, ACS)」が挙げられる. ACS は2014年からアセクシュ アル・コミュニティの有志が毎年実施しているオープン型ウェブ調査である。ここでは 2018年に実施された調査結果を取り上げる（Weis et al. 2020)。調査対象を13歳以上に

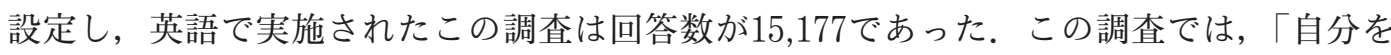
アセクシュアル・スペクトラムだと認識していますか？」という設問に「はい」(91.1\%) または「わからない」(4.2\%) と回答した人をAce とし，それ以外を非 Ace とした (Weis et al. 2020).

Ace アイデンティティの内訳は，アセクシュアル (65.9\%), デミセクシュアル (10.1 \%)，グレイアセクシュアル (11.8\%)，クエスチョニング（10.6\%)，その他（1.6\%）で あった。回答者の性自認は女性が $61.7 \%$ ，男性が $13.4 \% ，$ 該当なしが $24.8 \%$ て女，女性が全 体の約 $2 / 3$ 占め, 該当なし (男女以外の性自認) が $1 / 4$ 程度となった (Weis et al. 2020).

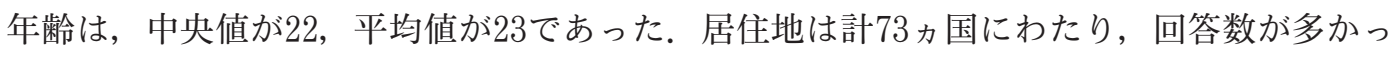




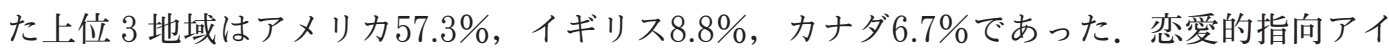
デンティティは複数回答で, 上位 5 つがアロマンティック $32.1 \%$, パンロマンティック (性別に関係なく恋愛的に惹かれる) $23.5 \%$ ，バイロマンティック $22.7 \%$ ，クエスチョニ ングまたはわからない（unsure）17.7\%，ヘテロロマンティック $17.4 \%$ という結果だった. 性的刺激を求める性欲（sex drives）／性衝動（libido）の強さを０から４で表すと，ア

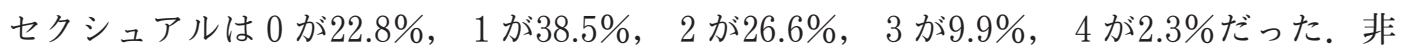
Ace 以外のカテゴリーは 1 が最も多かった点で共通していた一方，アセクシュアルは他の カテゴリーと比べて 0 の割合が高く， 2 以上の割合が低い傾向にあった. 自慰行為の頻度 については非 Ace が一番高く，アセクシュアルが一番低い結果だった．その他のカテゴ リーは前述の 2 カテゴリーの間に収まる結果を示した（Weis et al. 2020）.

\section{（3）日本における研究動向}

次に, 日本においてアセクシュアルを取り上げている量的調査について検討する。諸外 国と比べ，日本では性的指向をたずねる量的調査の数が少ないが，その中でも特にアセク シュアルまたはそれに類する選択肢を設けている調査はほとんどない. 現在日本に存在す る量的調查のうち, アセクシュアルの人口学的特徴を把握するデータとして最も重要なの は2019年に行われた「大阪市民の働き方と暮らしの多様性と共生にかんするアンケート」 （大阪市民調査）である（釜野他 2019）。この無作為抽出調査では，性的指向の要素とし て性的指向アイデンティティ，恋愛的惹かれ，性的惹かれ，性行動の 4 問がたずねられて いる．恋愛感情を抱く相手，性的に惹かれる相手，セックスの相手については，これまで と最近の 5 年間について聞いている。調査の結果，性的指向アイデンティティとして「ア セクシュアル・無性愛者」を選んだ回答者は0.8\%であることがわかった（Hiramori and Kamano 2020b). 他のセクシュアル・マイノリティのカテゴリーと比べると, 両性愛者 (1.4\%) よりは割合が低いものの同性愛者（0.7\%）とほぼ同じ割合である.また，出生 時の性別にみると, 出生時性別が男性の場合は回答者の $0.3 \%$ ア゙アクシュアルであるの に対し, 出生時性別が女性の場合は回答者の $1.1 \%$ ア゙アクシュアルであり, 諸外国の調 査でみられるアセクシュアルは男性に比べて女性の方が多いという結果が日本においても 確認された．年齢階級別にみると，30代および40代については回答者の $0.6 \% ， 50$ 代につ いては回答者の $0.7 \%$ がアクシュアルなのに対し，18-29歳層では回答者の $1.6 \%$ がアセ シュアルであり，アセクシュアルは若年層に多いという ACS 等の知見を確認する結果と なった (Hiramori and Kamano 2020b). 性的指向アイデンティティ以外の性的指向の 指標をみると, 出生時性別が女性のうち $2.9 \%$ がこれで男女どちらにも恋愛感情を抱い たことがなく，4.0\%がこれまで男女どちらにも性的に惹かれたことがない一方で，出生 時性別が男性のうち2.0\%がこれまで男女どちらにも恋愛感情を抱いたことがなく，1.5\% がこれまで男女どちらにも性的に惹かれたことがないことが明らかになった（釜野他 2019).

また，同じ大阪市民調查を用いて性的指向アイデンティティ，恋愛的惹かれ，性的惹か 
れ, 性行動の相互関連性を検討した研究もある (Hiramori and Kamano 2020a). 出生 時に割り当てられた性別と同じ性別を生きる人であるシスジェンダーの男女に対象を限定 した上で分析を行ったところ，アセクシュアル自認を持つ女性のうち約半数はこれまで 「男女どちらにも性的に惹かれたことがない」一方で，男性のみ（異性のみ）に性的に惹 かれる回答者が 4 割近くいることや, 恋愛的惹かれについてもアセクシュアル自認を持つ 女性のうち，これまで「男女どちらにも恋愛感情を抱いたことがない」回答者が約 4 割と， 男性のみ（異性のみ）に恋愛感情を抱く回答者の 5 割よりも割合が少ないことがわかった. 加えて, トランスジェンダーを含めた全回答者のうち $1.6 \%$ （出生時女性 : $2.1 \%$, 出生時 男性：0.9\%）が恋愛的惹かれも性的惹かれもこれまで感じたことがない（アロマンティッ ク・アセクシュアルに近いと考えられる）一方で, $1.3 \%$ （出生時女性：1.8\%, 出生時男 性：0.6\%）が恋愛的惹かれは感じるが性的惹かれのみこれまで感じたことがない（ロマ ンティック・アセクシュアルに近いと考えられる）ことが明らかになった。ささに，性的 惹かれがない人の性行動を検討したところ, 性的惹かれをこれまで感じたことがない人の うち 60.6\%はこれまで「セックスをしたことがない」一方で，38.6\%がセックス経験あり と回答していることがわかった (Hiramori and Kamano 2020a). 大阪市民調査の他に も, 埼玉県が無作為抽出調査を実施しており, 回答者の $0.7 \%$ がアクシュアルと自認し ている（埼玉県 2021）.

その他, 日本で行われたアセクシュアルに関連する量的調査としては，モニタ型ウェブ 調査の「2015年家族形成とキャリア形成についての全国調査」（Kobayashi 2017）がある. Kobayashi（2017: 14）はアセクシュアルを「キス，デート，性行為，恋愛関係を持つこ となどの性行動に関して経験ないし関心が少ない／低いこと」と定義し，ここで定義した アセクシュアルな人が増加することを「アセクシュアル化 (asexualized)」と呼んだ。分 析の結果，20代，30代女性はアセクシュアル化が観測されず，20代，30代男性はアセクシュ アル化が進んでいると報告した（Kobayashi 2017）。この研究は性別や年齢階級別にみた 性行動などの傾向を把握するのに有用である一方, 以下の 2 点からアセクシュアル研究と しては問題があると言わざるを得ない，1点目は，この研究がアセクシュアル研究におい て行動を定義とすることは一般的でないこと（Chasin 2011）や，性的な次元と恋愛的な 次元を分けてセクシュアリティを捉えること（Antonsen et al. 2020, Chu 2014）など, これまで行われてきたアセクシュアル研究の蓄積を反映していないことである．2 点目は， 本研究が少子化の文脈から議論されていることである。アセクシュアルというアイデンティ ティを持ち生活している人が現実に日本にもいる中で，少子化を「アセクシュアル」とい う言葉と結びつける形で表現すれば, アセクシュアルであることが少子化を生み出すと捉 えかねられない. そして, 政策上の課題とされる少子化の文脈の中でアセクシュアルを議 論することで, アセクシュアルそのものが問題であるかのような印象をつくり出す可能性 もある. 以上の点から, Kobayashi（2017）による研究はアセクシュアルではなく「性行 動の減少傾向」という枠組みで行った方が䛊解を招きにくいと考えられる.

上記で概観してきたように，日本においても近年，アセクシュアルの実態を把握可能な 
量的調査が数少ないながらも実施されるようになってきた. しかしながら，このような調 査を用いてアセクシュアルに関する実態を詳細に描写することは困難である。調査結果が 関心のある人口集団（例えば，日本に在住する人）に一般化可能かどうかという点におい ては大阪市民調査などのような無作為抽出調査の方が当事者団体等による有意抽出調查よ りも優れており，モニ夕型ウェブ調査にも特有の利点があるものの，マイノリティ当事者 が抱える困難などを詳述することが目的である場合，コミュニティ調査にも大きな意義が ある (Krueger et al. 2020). とりわけ，マイノリティ集団の中に存在する多様性を描く 際には，デー夕内に含まれるマイノリティ当事者の人数が多くなるような設計の調査が必 要である。しかしながら，これまで日本で行われてきた性的マイノリティ団体による既存 のコミュニティ調査においてもアセクシュアル回答者は少なく，独立した性的指向として 扱われないことが多い（例えば，認定 NPO 法人虹色ダイバーシティ・国際基督教大学ジェ ンダー研究センター（2020）による調査など）。したがって，日本においても性的マイノ リティ全体を対象にした調査ではなく ACS のようなアセクシュアルに特化した調査が求 められている状況がある。 そこで本論文では，このようなアセクシュアルに焦点を当てた 調査研究を行うべく立ち上げられたAro/Ace 調査実行委員会が実施した「Aro/Ace 調査 $2020 」$ を分析し，日本におけるアセクシュアルの人口学的多様性を示す.

III. データと方法

\section{1. データ}

本論文では, Aro/Ace 調査実行委員会によって実施された調査である「Aro/Ace 調査 $2020 」$ を使用する. 調査目的は「(1）Aro/Aceの可視化を促す，（2）Aro/Aceコミュニ ティに集まる人たちの多様性について議論するための情報を収集する，（3）Aro/Ace に 関する情報を提供し, 学術研究の発展やAro/Aceに関する運動の活性化に寄与する」 (Aro/Ace 調査実行委員会 2020）ことであり，「(1) アロマンティック／アセクシュアル・ スペクトラムを自認している，またはそれに近い，そうかもしれないと思っている方，

（2）日本語の読み書きをする方（国籍, 居住地は問わない), (3) 年齢が回答時13歳以上 の方」(Aro/Ace 調査実行委員会 2020）を調査対象者としている. 設問の設計にあたっ ては，日本の文脈において「アセクシュアル」という用語が，恋愛的惹かれと性的惹かれ のいずれもない人を指すことがあるため, 恋愛感情に関連する設問を先に配置し, 適宜調 査内で使用する語の用法を明記するようにするなど，回答者ができるだけ正確に回答でき るよう工夫を行った。調査手法としては, 本調查はオープン型ウェブ調查であり, Aro/Ace 調査実行委員会のウェブサイト，ソーシャル・ネットワーキング・サービスの Twitter や当事者 LINE グループなどで調査の周知を行った。 ウェブ上のアンケートフォー ムで回答者が調査への協力に同意した後, 自主的に回答する形式をとっている. 調査対象 者に該当するかに関する項目や設問の分岐に必要な項目以外はすべて任意回答となってい る。調查は 2020 年 6 月 1 日から 6 月30日まで行われ，合計1,693の回答が集まった。その 
うち，「自分のことをアロマンティック／アセクシュアル・スペクトラム（Aro/Ace）に 当てはまると思いますか. 本調査では，アロマンティック／アセクシュアル・スペクトラ ムを，アロマンティック，アセクシュアル，ノンセクシュアル，デミセクシュアル，デミ ロマンティック，リスセクシュアル，リスロマンティックなどその他周辺のセクシュアリ ティという意味で用います.」という設問に対して「いいえ」と回答した 8 人を除外した 1,685を有効回収数とした。なお，日本語の読み書きおよび年齢の条件をもとに除外した 回答はなかった。調査の詳細についてはAro/Ace 調查実行委員会（2020）に記載されて いる。

\section{2. 方法}

本論文では, まず回答者の性別, 年齢階級, 居住地の分布を検討する. 次に, 先行研究 を踏まえた上で特に重要だと考えられる項目であるアロマンティック・スペクトラムのア イデンティティ，アセクシュアル・スペクトラムのアイデンティティの分布を性別，年齢 階級別に示す。その後，ロマンティック・アセクシュアルに分析対象を限定した上で日本 独自の区分であるノンセクシュアル自認の分布を性別，年齢階級別に示す。最後に，自慰 行為の頻度，性欲の有無，他者と性行為をしょうと思うことがあるか否かの分布をアセク シュアル・スペクトラムのアイデンティティ別に示す.

IV. 結果

\section{1. 回答者の分布}

本節では，調查回答者の分布を示す。ここでは特に，性別，年齢階級，居住地に注目し， 回答者の人口学的特徵を把握する。なお，サンプルの代表性についてはAro/Ace 調査実 行委員会（2020）で詳細に検討されている. 本調査における回答者の人口学的特徴が国勢 調查などの分布と異なっていることを調査手法など技術的な要因によるバイアスとして捉 えるべきなのか，日本におけるアロマンティック／アセクシュアル・スペクトラムの傾向 を正確に表わしていると考えるべきなのかについては，今後さらなる研究が求められる. 本論文では両方の可能性を踏まえた上で，考察を行っていく.

表 1 は，回答者の分布を性別にみたものである．回答者のうち，シスジェンダー女性は 62.7\%，シスジェンダー男性は $4.7 \% ，$ 非シスジェンダーは $32.5 \%$ オあり，シスジェンダー 女性の割合が最も高かった，本調査では，「出生時の性別と，現在自分が捉えている性別 が「一致」していると思いますか」という質問に「思う」と回答した人にのみ出生時性別 を聞いている（性自認は全回答者にたずねている）。そのため，上記質問に「思わない」 または「分からない」と回答した人の出生時性別は不明である。なお本論文では，この質 問に対して「思う」と回答した人をシスジェンダー，それ以外の回答をした人を非シスジェ ンダーと分類する。出生時性別が人口学的に重要な情報であることは疑いようがないもの の，出生時性別を質問することはとりわけ非シスジェンダーに該当する人にとって配慮す 
べき事項であるため，以上のような設計になっている，以下，本分析では，シスジェンダー 女性, シスジェンダー男性, 非シスジェンダーの 3 カテゴリーからなる性別の分類を用い る.

表 1 性別にみた回答者の分布（Aro/Ace 調査2020）

\begin{tabular}{lrr}
\hline & 度数 & パーセント \\
\hline シスジェンダー女性 & 1,056 & 62.7 \\
シスジェンダー男性 & 80 & 4.7 \\
非シスジェンダー & 547 & 32.5 \\
無回答 & 2 & 0.1 \\
\hline 合計 & 1,685 & 100.0 \\
\hline
\end{tabular}

表 2 は回答者の分布を年齢階級別にみたものである。実際の設問では, 調査回答日時点 の実年齢をたずねている．回答者のうち，10代は $11.2 \% ， 20$ 代は $62.0 \% ， 30$ 代は $21.1 \% ， 40$ 代以上は $5.8 \%$ であり，20代の割合が最も高かった。なお，年齢の中央値は 25.0 , 平均值 は26.5，標準偏差は6.9で，13-63歳からの回答があった。

表 2 年齢階級別にみた回答者の分布（Aro/Ace 調査2020）

\begin{tabular}{lrr}
\hline & 度数 & パーセント \\
\hline 10 代 & 188 & 11.2 \\
20 代 & 1,045 & 62.0 \\
30 代 & 355 & 21.1 \\
40 代以上 & 97 & 5.8 \\
\hline 合計 & 1,685 & 100.0 \\
\hline
\end{tabular}

表 3 は回答者の分布を居住地別にみたものである。実際の設問では，都道府県および 「日本以外」が選択肢として配置されている。回答者のうち, 東京都在住は $25.3 \%$, 千葉 県・埼玉県・神奈川県在住は $22.2 \%$, 京都府・大阪府・兵庫県在住は $12.8 \%$, 静岡県以東 の東日本在住は $17.2 \%$, 石川県・愛知県以西の西日本在住は $18.2 \%$ であり, 東京都在住の 割合が最も高かった。

表 3 居住地別にみた回答者の分布（Aro/Ace 調査2020）

\begin{tabular}{lrc}
\hline & 度数 & パーセント \\
\hline 東京都 & 426 & 25.3 \\
千葉県・埼玉県・神奈川県 & 374 & 22.2 \\
京都府・大阪府・兵庫県 & 215 & 12.8 \\
東日本 (〜静岡県) & 289 & 17.2 \\
西日本 (石川県・愛知県 ) & 307 & 18.2 \\
日本以外 & 9 & 0.5 \\
無回答 & 65 & 3.9 \\
\hline 合計 & 1,685 & 100.0 \\
\hline
\end{tabular}

\section{2. 主要項目の結果}

本節では，アロマンティック・スペクトラムのアイデンティティ，アセクシュアル・ス 
ペクトラムのアイデンティティ, ノンセクシュアル自認, 自慰行為の頻度, 性欲の有無, 他者と性行為をしようと思うことがあるか否かの分布を示す.

表 $4 \mathrm{a}$ および $4 \mathrm{~b}$ は，性別および年齢階級別にアロマンティック・スペクトラム・アイ デンティティの分布をみたものである。実際の設問では, 自認しているカテゴリーの選択 肢として「ロマンティック【恋愛的に惹（ひ）かれる】，アロマンティック，グレイアロ マンティック/グレイロマンティック，デミロマンティック，リスロマンティック，クエ スチョニング，Aro/Ace を自認していない，その他」が配置されている．分析にあたっ て，クエスチョニング，Aro/Aceを自認していない，その他を「その他」として再コー ディングした，回答者のうち，48.0\%がアロマンティックであり，最も割合が高かった.

性別にみると，シスジェンダー男性はシスジェンダー女性や非シスジェンダーに比べてロ マンティックを自認する割合が高い結果となり，性別による差がみられた。 その一方，年 齢階級とアロマンティック・スペクトラム・アイデンティティの間に $10 \%$ 水準で統計的に 有意な連関はみられなかった

表 4 a 性別にみたアロマンティック・スペクトラム・アイデンティティの分布（Aro/Ace 調査2020）

\begin{tabular}{lrrrr}
\hline （\%) & シス女性 & シス男性 & 非シスジェンダー & \multicolumn{1}{c}{ 全体 } \\
\hline アロマンティック & 49.0 & 51.2 & 45.5 & 48.0 \\
グレイ（ア）ロマンティック & 7.0 & 10.0 & 8.8 & 7.7 \\
デミロマンティック & 11.1 & 6.3 & 9.1 & 10.2 \\
リスロマンティック & 6.1 & 1.3 & 6.4 & 5.9 \\
ロマンティック & 13.3 & 27.5 & 10.6 & 13.1 \\
その他 & 12.5 & 2.5 & 18.8 & 14.1 \\
無回答 & 1.1 & 1.3 & 0.7 & 1.0 \\
\hline $\mathrm{n}$ & 1,056 & 80 & 547 & 1,685 \\
\hline
\end{tabular}

$\chi^{2}: 45.323(p<.001)$, Cramer's V $: 0.095(p<.001)$

注：性別が無回答である回答者（n=2）の結果は示していないが，「全体」は性別無回答を含む．

表 $4 \mathrm{~b}$ 年齢階級別にみたアロマンティック・スペクトラム・アイデンティティの分布（Aro/Ace 調査2020）

\begin{tabular}{lrrrrr}
\hline ％） & 10代 & \multicolumn{1}{c}{ 20代 } & \multicolumn{1}{c}{30 代 } & \multicolumn{1}{c}{40 代以上 } & \multicolumn{1}{c}{ 全体 } \\
\hline アロマンティック & 45.7 & 47.7 & 51.3 & 44.3 & 48.0 \\
グレイ（ア）ロマンティック & 8.5 & 7.6 & 8.2 & 6.2 & 7.7 \\
デミロマンティック & 8.5 & 10.9 & 9.6 & 8.2 & 10.2 \\
リスロマンティック & 5.3 & 6.5 & 4.2 & 7.2 & 5.9 \\
ロマンティック & 11.7 & 12.9 & 13.2 & 16.5 & 13.1 \\
その他 & 19.1 & 13.7 & 12.7 & 13.4 & 14.1 \\
無回答 & 1.1 & 0.8 & 0.8 & 4.1 & 1.0 \\
\hline $\mathrm{n}$ & 188 & 1,045 & 355 & 97 & 1,685 \\
\hline
\end{tabular}

$\chi^{2}: 21.401(p=.260)$, Cramer's V : $0.065(p=.260)$

21）なお，シスジェンダー女性，シスジェンダー男性，非シスジェンダーそれぞれについて年齢階級別にみたア ロマンティック・スペクトラム・アイデンティティの分布も検討したが，シスジェンダー女性については $10 \%$ 水準で統計的に有意な連関はみられなかった $(p=.909)$. シスジェンダー男性については, 期待度数 5 未満の セルが85.7\%であったためモンテカルロ・シミュレーションを行った上でカイ二乗検定を行った $(p=.036 ; 99$ $\%$ 信頼区間 $=.031-.040)$. 回答者のうち10代および20代は30代および40代以上と比べてロマンティックを自 認する割合が高かったが，ケース数が 80 と少ないこともあり，結果の解釈には注意が必要である．非シスジェ ンダーについては，若年層は中高年層と比べて「その他」と回答する割合が高いことがわかった $(p=.001)$. 
表 $5 \mathrm{a}$ および $5 \mathrm{~b}$ は, 性別および年齢階級別にアセクシュアル・スペクトラム・アイデ ンティティの分布をみたものである. 実際の設問では, 自認しているカテゴリーの選択肢 として「セクシュアル【性的に惹（ひ）かれる】，アセクシュアル，グレイアセクシュア ル/グレイセクシュアル，デミセクシュアル，リスセクシュアル，Aro/Aceを自認して いない，その他」が配置されている。なお，調查設計上のエラーにより，「クエスチョニ ング」は選択肢に含まれていない，分析にあたって，Aro/Ace を自認していない，その 他を「その他」として再コーディングした．回答者のうち，65.6\%がアセクシュアルであ り，最も割合が高かった。性別にみると，シスジェンダー女性や非シスジェンダーはシス ジェンダー男性に比べてアセクシュアルを自認する割合が高い一方でセクシュアルを自認 する割合が低いなど，性別による差がわずかながらみられた。 その一方，年齢階級とアセ クシュアル・スペクトラム・アイデンティティの間に $10 \%$ 水準で統計的に有意な連関はみ られなかった ${ }^{22)}$.

表 5 a 性別にみたアセクシュアル・スペクトラム・アイデンティティの分布（Aro/Ace 調査2020）

\begin{tabular}{lrrrr}
\hline ％） & シス女性 & シス男性 & 非シスジェンダー & \multicolumn{1}{c}{ 全体 } \\
\hline アセクシュアル & 65.9 & 60.0 & 66.2 & 65.6 \\
グレイ（ア）セクシュアル & 8.4 & 12.5 & 7.7 & 8.4 \\
デミセクシュアル & 9.1 & 5.0 & 5.9 & 7.8 \\
リスセクシュアル & 2.6 & 1.3 & 3.5 & 2.8 \\
セクシュアル & 8.0 & 13.8 & 9.1 & 8.7 \\
その他 & 5.4 & 6.3 & 6.9 & 6.0 \\
無回答 & 0.7 & 1.3 & 0.7 & 0.7 \\
\hline $\mathrm{n}$ & 1,056 & 80 & 547 & 1,685 \\
\hline
\end{tabular}

$\chi^{2}: 26.957(p=.080)$, Cramer's V : $0.073(p=.080)$

注：性別が無回答である回答者（n=2）の結果は示していないが，「全体」は性別無回答を含む.

表 $5 \mathrm{~b}$ 年齢階級別にみたアセクシュアル・スペクトラム・アイデンティティの分布（Aro/Ace 調査2020）

\begin{tabular}{lrrrrr}
\hline ％） & 10 代 & 20 代 & 30 代 & 40代以上 & 全体 \\
\hline アセクシュアル & 65.4 & 65.5 & 67.3 & 61.9 & 65.6 \\
グレイ (ア) セクシュアル & 8.0 & 7.8 & 9.6 & 11.3 & 8.4 \\
デミセクシュアル & 4.3 & 8.6 & 7.6 & 7.2 & 7.8 \\
リスセクシュアル & 4.3 & 2.7 & 2.0 & 4.1 & 2.8 \\
セクシュアル & 10.6 & 8.5 & 8.7 & 6.2 & 8.7 \\
その他 & 5.9 & 6.2 & 4.5 & 9.3 & 6.0 \\
無回答 & 1.6 & 0.8 & 0.3 & 0.0 & 0.7 \\
\hline $\mathrm{n}$ & 188 & 1,045 & 355 & 97 & 1,685 \\
\hline
\end{tabular}

$\chi^{2}: 17.871(p=.464)$, Cramer's V : $0.059(p=.464)$

22）なお，シスジェンダー女性，シスジェンダー男性，非シスジェンダーそれぞれについて年齢階級別にみたア セクシュアル・スペクトラム・アイデンティティの分布も検討したが，シスシェンダー女性については $10 \%$ 水 準で統計的に有意な連関はみられなかった（ $p=.636 ）$. シスジェンダー男性については，期待度数 5 未満の セルが82.1\%であったためモンテカルロ・シミュレーションを行った上でカイ二乗検定を行った（ $p=.065 ;$ 99\%信頼区間 =.058-.071). しかしながら，ケース数が80と少ないこともあり，特定の回答傾向はみられな かった. 非シスジェンダーについては $10 \%$ 水準で統計的に有意な連関はみられなかった $(p=.522)$. 
表 $6 \mathrm{a}$ および $6 \mathrm{~b}$ は，性別および年齢階級別にノンセクシュアル自認の分布をみたもの である．分析にあたっては，日本においてノンセクシュアルという用語がロマンティック のアセクシュアルに近い意味で用いられていることを踏まえ，ロマンティック・アセクシュ アルのみに分析対象を絞っている。また，実際の設問では，選択肢として「はい，いいえ， 言葉を聞いたことがない，言葉を聞いたことはあるが意味を知らない，分からない，その 他」が配置されているが，言葉を聞いたことがない，言葉を聞いたことはあるが意味を知 らない，分からない，その他を「その他」として再コーディングした. ロマンティック・ アセクシュアル回答者のうち，80.7\%がノンセクシュアルを自認していた．性別とノンセ クシュアル自認の間に $10 \%$ 水準で統計的に有意な連関はみられなかった．年齢階級別にみ ると, 回答者のうち 10 代は 20 代および 30 代に比べてノンセクシュアルを自認する割合が低 かった。しかし，40代も10代ほどではないもののノンセクシュアル自認割合が低く，さら に10代と40代については該当者数が少ないため, 結果の解釈には注意が必要である.

表 6 a 性別にみたノンセクシュアル自認の分布（Aro/Ace 調査2020）

\begin{tabular}{lrrrr}
\hline ％） & シス女性 & シス男性 & 非シスジェンダー & \multicolumn{1}{c}{ 全体 } \\
\hline はい & 81.5 & 93.3 & 73.8 & 80.7 \\
いいえ & 6.7 & 6.7 & 11.9 & 8.0 \\
その他 & 11.8 & 0.0 & 14.3 & 11.4 \\
\hline $\mathrm{n}$ & 119 & 15 & 42 & 176 \\
\hline
\end{tabular}

$\chi^{2}: 3.673(p=.452)$, Cramer's V : $0.102(p=.452)$

表 $6 \mathrm{~b}$ 年齢階級別にみたノンセクシュアル自認の分布（Aro/Ace 調査2020）

\begin{tabular}{lrrrrr}
\hline (\%) & 10代 & 20 代 & 30 代 & \multicolumn{1}{c}{40 代以上 } & 全体 \\
\hline はい & 66.7 & 83.2 & 82.5 & 72.7 & 80.7 \\
いいえ & 27.8 & 4.7 & 10.0 & 0.0 & 8.0 \\
その他 & 5.6 & 12.1 & 7.5 & 27.3 & 11.4 \\
\hline $\mathrm{n}$ & 18 & 107 & 40 & 11 & 176 \\
\hline$\chi^{2}: 15.618(p=.016)$, Cramer's V $: 0.211(p=.016)$ & & &
\end{tabular}

表 7 ，表 8 ，表 9 は，それぞれアセクシュアル・スペクトラム・アイデンティティ別に 自慰行為の頻度，性欲の有無，他者と性行為をしょうと思うことがあるか否かの分布をみ たものである。自慰行為の頻度については10段階のものを 5 段階に変換し，言葉の意味が わからない，無回答，その他を「その他」として再コーディングした．性欲の有無，他者 との性行為に対する態度については 5 段階のリッカート尺度を 3 段階のものに変換した. また分析にあたって，アセクシュアル・スペクトラム・アイデンティティのうち，グレイ アセクシュアル／グレイセクシュアル，デミセクシュアル，リスセクシュアルを「アセク シュアル周辺カテゴリー」として再コーディングした.

表 7 によると，アセクシュアル回答者のうち $32.9 \%$ が 1 回〜週 1 回の頻度で自慰行為 を行っており，アセクシュアルの回答者の中で最も割合が高かった。また，週 2 回以上の 回答者屯 $16.5 \%$ い。 アセクシュアル周辺カテゴリーやセクシュアル回答者はアセクシュ 
アル回答者に比べて自慰行為の頻度が高く，アセクシュアル・スペクトラム・アイデンティ ティ別による差がみられた。

表 7 アセクシュアル・スペクトラム・アイデンティティ別にみた自慰行為の頻度の分布 (Aro/Ace 調査 2020)

\begin{tabular}{lccccc}
\hline (\%) & アセクシュアル & 周辺カテ & セクシュアル & その他 & 全体 \\
\hline 一度も自慰行為をしたことが & 17.7 & 7.8 & 4.8 & 9.9 & 14.2 \\
ない & & & & & \\
以前は自慰行為をしていたが, & 7.4 & 2.2 & 0.7 & 7.9 & 5.9 \\
現在はしていな & & 9.4 & 6.8 & 5.9 & 9.8 \\
月 1 回未満 & 10.6 & 41.3 & 28.8 & 41.6 & 34.6 \\
月 1 回 週 1 回 & 32.9 & 24.7 & 50.0 & 22.8 & 21.4 \\
週 2 回以上 & 16.5 & 14.7 & 8.9 & 11.9 & 14.1 \\
その他 & 14.8 & 320 & 146 & 101 & 1,685 \\
\hline $\mathrm{n}$ & 1,106 & & & & \\
\hline
\end{tabular}

$\chi^{2}: 134.574(p<.001)$, Cramer's V:0.141 $(p<.001)$

注：アセクシュアル・スペクトラム・アイデンティティが無回答である回答者 $(\mathrm{n}=12)$ の結果は示していな いが「全体」はアセクシュアル・スペクトラム・アイデンティティ無回答を含む.「周辺カテ」=アセクシュ アル周辺カテゴリー.

表 8 によると，アセクシュアル回答者のうち $66.4 \%$ が性欲があると思うと答えており， アセクシュアルの回答者の中で最も割合が高かった。 アセクシュアル周辺カテゴリーやセ クシュアル回答者はアセクシュアル回答者に比べて性欲があると思う割合が高く，アセク シュアル・スペクトラム・アイデンティティ別による差がみられた.

表 8 アセクシュアル・スペクトラム・アイデンティティ別にみた性欲の有無の分布 (Aro/Ace 調査2020)

\begin{tabular}{lrrrrr}
\hline (\%) & アセクシュアル & 周辺カテ & セクシュアル & その他 & 全体 \\
\hline 思う & 66.4 & 89.1 & 96.6 & 76.2 & 73.9 \\
ごちらでもない & 6.1 & 2.2 & 0.7 & 7.9 & 5.0 \\
思わない & 27.1 & 8.8 & 2.7 & 14.9 & 20.7 \\
無回答 & 0.4 & 0.0 & 0.0 & 1.0 & 0.3 \\
\hline $\mathrm{n}$ & 1,106 & 320 & 146 & 101 & 1,685 \\
\hline
\end{tabular}

$\chi^{2}: 115.748(p<.001)$, Cramer's V $: 0.151(p<.001)$

注：アセクシュアル・スペクトラム・アイデンティティが無回答である回答者 $(\mathrm{n}=12)$ の結果は示していな いが，「全体」はアセクシュアル・スペクトラム・アイデンティティ無回答を含む.「周辺カテ」=アセクシュ アル周辺カテゴリー。

表 9 によると，アセクシュアル回答者のうち $91.6 \%$ が他者と性行為をしようと思うこと がないと答えており，アセクシュアルの回答者の中で最も割合が高かった。 アセクシュア ル周辺カテゴリーやセクシュアル回答者はアセクシュアル回答者に比べて性行為をしょう と思うことがないと答える割合が低く，アセクシュアル・スペクトラム・アイデンティティ 別による差がみられた。 
表 9 アセクシュアル・スペクトラム・アイデンティティ別にみた他者と性行為をしようと思うこ とがあるか否かの分布 (Aro/Ace 調査2020)

\begin{tabular}{lrrrrr}
\hline$(\%)$ & アセクシュアル & 周辺カテ & セクシュアル & その他 & \multicolumn{1}{c}{ 全体 } \\
\hline ある & 6.1 & 26.9 & 67.8 & 26.7 & 16.7 \\
どちらでもない & 2.1 & 4.7 & 3.4 & 5.0 & 2.8 \\
ない & 91.6 & 68.4 & 27.4 & 67.3 & 80.1 \\
無回答 & 0.3 & 0.0 & 1.4 & 1.0 & 0.4 \\
\hline $\mathrm{n}$ & 1,106 & 320 & 146 & 101 & 1,685 \\
\hline
\end{tabular}

$\chi^{2}: 421.035(p<.001)$, Cramer's V $: 0.289(p<.001)$

注：アセクシュアル・スペクトラム・アイデンティティが無回答である回答者 $(\mathrm{n}=12)$ の結果は示していな いが，「全体」はアセクシュアル・スペクトラム・アイデンティティ無回答を含む.「周辺カテ」=アセクシュ アル周辺カテゴリー.

表 7 , 表 8 , 表 9 から, 自慰行為の頻度と性欲の有無については, アセクシュアル回答 者の多くがその存在を示すような回答をしていたのに対し, 他者との性行為をしようと思 うことがあるか否かについては，アセクシュアル回答者のほとんどがないという回答をし ていることがわかった。

\section{V. 考察}

\section{1. 結果の解釈}

本研究では, 日本におけるアロマンティック/アセクシュアル・スペクトラムの人口学 的多様性を記述すべく, Aro/Ace 調査実行委員会によって実施された「Aro/Ace 調査 $2020 」$ を分析した。 以下，分析で得られた結果の解釈を述べる.

はじめに，回答者の性別は女性が多く，男性は少ないという先行研究（Bogaert 2004， Hiramori and Kamano 2020b）と同様の傾向が本研究でも確認された。さらに，非シ スジェンダーの割合がシスジェンダー男性よりも高いという当事者団体による調査結果 （Weis et al. 2020）とも類似した結果となった。 アセクシュアルに女性が多い背景とし て性役割，性機能，性行動などが関係している可能性も指摘されているが（Bogaert 2004)，アセクシュアルをはじめとするアイデンティティになぜシスジェンダー女性が多 く集めるのかなど，性別による分布の違いについては明らかになっていないことも多い (Carroll 2020). 一方，Aro/Ace コミュニティにおいて非シスジェンダーが相対的に多 いことについては，性的なパートナーを魅了する必要がないことと関連性があるという指 摘がある（Chasin 2011）。 また，別の視点として，Aro/Aceをとりまく環境が自認から 遠ざけている可能性も考えられる。例えば，アセクシュアルは知名度が低いこともあり， 違和感を持ったとしても調べるなどして言葉に出会わなければ自認しない可能性がある （吉岡 2019）。したがってAro/Aceに近い特徵（例えば，恋愛的／性的惹かれを感じない） があったとしても自認しない／できないことがある．自認するためには他の要素，ここで は性自認のあり方がシスジェンダーでないことなどがアセクシュアルに繋がる機会を提供 している可能性が指摘できる。 
年齢階級については，本調査の回答者は年齢層が低いことがわかり，自認を基準とした 場合にアセクシュアルは相対的に年齢が低かったという結果 (Hiramori and Kamano 2020b）を支持する形となった。当事者団体による調査でも同様の傾向が確認されている が（Weis et al. 2020)，性的惹かれを基準とした場合ではアセクシュアルと非アセクシュ アルで年齢差はほとんどなかったと報告されており（Bogaert 2004），自認を基準とした 方が年齢は低い傾向になることが示唆される。本調査における回答者の年齢が低い要因と して，オープン型ウェブ調査という調査法の特性も理由として挙げることができるが，自 認を基準とした場合に年齢が低くなる重要な背景としてAro/Ace に関する情報媒体の偏 りが考えられる。近年では雑誌などインターネット以外でAro/Ace に関する情報を手に 入れることも可能になりつつあるが（例えば，大川 2018），日本語で書かれたアセクシュ アルに関する書籍は非常に少ないため（例えば，デッカー 2019），インターネットを介し た情報が多いと推測される。インターネットはこれまでもアセクシュアル（または Aro/Ace）にとってアイデンティティ形成やコミュニティの形成，情報発信をする重要 な場であると指摘されてきた（三宅 2017，Pacho 2013）。以上を，言葉を知ることが自 認の契機となる点（吉岡 2019）と合わせて推論すれば，個人がどの媒体から情報にアク セスできるかということが自認にも影響することになる。つまり，Aro/Aceに関する情 報を手に入れやすいインターネットとの関わり方の違いが自認のしやすさに影響し，結果 として当事者コミュニティの構成員の年齢分布が若年層に偏っている可能性がある.

次に，アロマンティック・スペクトラム・アイデンティティに関する結果から，性別に よる違いが確認された。しかし，海外の研究ではアセクシュアルの中でアロマンティック とロマンティックの分布に性別による差はなかったと報告されており (Antonsen et al. 2020)，先行研究とは異なる結果となった。本研究でシスジェンダー男性にロマンティッ ク自認が多い要因として，先行研究の測定方法との違いがあると考えられる．先行研究で は，アロマンティックとロマンティックの区別を恋愛的に惹かれる頻度や性別で測定して いる（Antonsen et al. 2020）。本研究とは恋愛的惹かれと自認という点で測定方法に違 いがあることに加え，アロマンティック・スペクトラムのアイデンティティには惹かれる 性別や頻度だけではなく，惹かれの仕方に関するものがある。本研究でいえば，情緒的な 繋がりができてからのみ恋愛的惹かれを感じるデミロマンティック，恋愛感情が返される ことを必要としない形で恋愛的に惹かれるリスロマンティックがそれにあたる。本研究で はデミロマンティックやリスロマンティックがシスジェンダー男性と比べてシスジェンダー 女性と非シスジェンダーに多い傾向が示されたが，先行研究は惹かれの仕方に関して結果 に反映できていない可能性がある，そのため，先行研究ではロマンティック女性を多く見 積もり，性別による差がないという結果になったと考えられる．性別によってアロマンティッ ク・スペクトラム・アイデンティティの分布に差があるという本研究の結果が，日本特有 の状況または有意抽出調査であることに由来する可能性も十分に考えられるが，測定法の 違いによる可能性も考慮すべきだと思われる。そして，これはAro/Aceに関する調査に おいて，惹かれの性別や有無（頻度）だけでなく惹かれの仕方も重要な側面であることを 
示唆している.

自慰行為の頻度に関してアセクシュアル・スペクトラム・アイデンティティ別にみると, アセクシュアルが最も頻度が少ない結果になり，当事者団体による調査で確認されている 傾向（Weis et al. 2020）が本調査でも認められた. この点について，アセクシュアルの 自認と自慰行為の頻度の関連性も想定されるが，アセクシュアルの中で「自慰行為をした ことがない」と「以前は自慰行為をしていたが，現在はしていない」を合わせた割合より も，「月 1 回〜週 1 回」の回答の方が多かったことは注目に值する。アセクシュアルの自 認と自慰行為の頻度は関連している可能性が高いものの, 自慰行為の有無のみがアセクシュ アルのアイデンティティ形成に決定的な影響力をもたらしているとは言えないことが示唆 される.

続いて性欲の有無に関しても, 自慰行為の頻度と同様にアセクシュアルが最も性欲が弱 い傾向が確認され，先行研究と同様の結果だった（Weis et al. 2020）。しかしながらア セクシュアルを自認する人の中で 6 割以上が性欲があると回答しており, 自慰行為の頻度 に関する結果と合わせると，日本においても自慰行為は他者に向かない性欲でありアセク シュアルであることと矛盾しない（Hinderliter 2013）と理解されていると考えられる.

一方で，他者と性行為をしようと思うことがあるか否かに関しては，自慰行為の頻度お よび性欲の有無と異なる傾向が確認された。 セクシュアル自認以外のアイデンティティで は他者と性行為をしようと思うことが少なく，特にアセクシュアルではその傾向が顕著で あった。これはアセクシュアルの自慰行為に対する欲望（desire）は他のセクシュアリティ と変わらないものの, 他者と性行為をする欲望が低いという研究結果 (Prause and Graham 2007）を支持するものである。この結果は，他者との性行為をしようと思うか 否かが自認において準拠点となる可能性を示唆している.つまり, 自慰行為や性欲は自認 と矛盾しない一方で，他者との性行為が自認もしくはAro/Aceコミュニティに参加する 基準となっている可能性がある。これは他者と性行為をする欲望や性行動がないことによっ てアセクシュアルを自認することもあるという研究結果（Scherrer 2008）を部分的に肯 定するものである.しかし, 近年の海外におけるアセクシュアル研究では, 性的欲望や性 行動の欠如ではなく性的惹かれの欠如として捉えるのが一般的になってきており （Chasin 2011），他者との性行為をしょうと思わないことと自認の関連性は慎重な議論を 要する. 性的惹かれを定義とすることの有用性として, 性行為をするアセクシュアルを排 除すべきとする立場と距離を取ることが可能になる点が指摘されているように (Hinderliter 2013), Aro/Aceコミュニティにおいて性行為をしようと思うか否かが重 要な意味を持っていたとしても，それを自認の要件として扱ってはならないと考えられる.

この他，本研究の結果として，海外の当事者団体による調査結果（Weis et al. 2020） と同様にアセクシュアルを自認する人が 6 割以上だった一方で, 当事者コミュニティが必 ずしもアセクシュアル自認の人のみで構成されているわけではないことが明らかになった。 さらに，ノンセクシュアルに関して，ロマンティックとアセクシュアルを自認する人の 8 割以上がノンセクシュアルと自認していることがわかった. 日本のAro/Ace コミュニティ 
において，ノンセクシュアルがロマンティック・アセクシュアルと類似する概念として使 用されている可能性が高いことが示された。

\section{2. 今後の展望}

本研究は日本におけるアロマンティック／アセクシュアル・スペクトラムの人口学的多 様性を記述したが, 限界点がまったくないわけではない, 本研究には, 以下 3 つの限界点 がある．第 1 に，本研究で使用したデー夕は当事者コミュニティを対象とした調査を基に しており，本研究の結果を日本国内の人口一般に適用することには留意が必要な点である. $\lceil$ Aro/Ace 調查2020」はマイノリティ集団を調查対象としており，関心層にアプローチし やすいオープン型ウェブ調査のメリットはあるものの，性別や年齢階級，居住地の分布を 明らかにするためには日本全国を対象とした無作為抽出調査が必要である。第 2 に，本研 究がアプローチした当事者コミュニティの層には偏りがあると考えられる点である．アセ クシュアルを自認する人の中で恋愛的に惹かれない人よりも惹かれる人の方が多い可能性 が報告されているが (Hiramori and Kamano 2020a), 本研究ではロマンティック自認 が13\%という結果になっており, ロマンティックのAce スペクトラム当事者による回答 を十分に得られなかった可能性がある。アロマンティックとロマンティックでは異なる背 景, 状況, 認識があると考えられるため, ロマンティックまたはアロマンティック・スペ クトラム・アイデンティティの多様性を把握可能な調査設計をする必要がある. 第 3 に, 本研究では量的調査の特性上, 各結果の意味や背景を解釈するのには限界がある点である. 例えば，本論文では自慰行為の頻度について分析したが，そもそも自慰行為とは Aro/Aceによってどのような意味を持つものなのかを本研究では検討することができな い. 他にも, Aro/Aceのアイデンティティと性別の関係性について海外では性役割の観 点から指摘する研究が増えつつあるが（例えば, Gupta 2019, Przybylo 2014, Vares 2018),Aro/Ace によって日本社会の性役割はどのような意味を持ち，それが自認に影響 するのかについては質的研究を含めた多様なアプローチから研究することが望まれる.

本研究では, 既存の人口学研究 (Bogaert 2004, Hiramori and Kamano 2020b, Poston and Baumle 2010）では記述されてこなかった, Aro/Aceに関わるアイデンティ ティの多様性や自慰行為・性欲・性行為をしようと思うか否かの関係性について提示した. 今後は，本論文で分析した調査項目以外の分析を行いたいと考えている．例えば，「Aro/ Ace 調查2020」には自認の他に恋愛的／性的惹かれの対象や有無に関する項目があり，自 認と惹かれの関連性について検討することができる。また，恋愛的／性的惹かれの対象や 有無の項目は自認前と自認後で分けて質問しており，自認前後によって惹かれの経験に差 ができるのかも検討可能である. 加えて, 性行為人数や性的な魅力を感じるか否か, 付き 合いたいと思うか，独占欲があると思うかなど，各項目が自認とどのような関係性にある のかについても今後の研究課題としたい.アセクシュアルが社会における強制的性愛の可 視化に有用である（Chasin 2014）ならば, 本研究もその営為に貢献しうるだろう. 本研 究の結果ならびに限界点を踏まえた今後のアロマンティック／アセクシュアル・スペクト 


\section{参照文献}

Aro/Ace 調査実行委員会（2020）『アロマンティック／アセクシュアル・スペクトラム調査2020概要報告』

https://ace-community-survey.jimdosite.com/（2021年 2 月25日最終アクセス）.

エヴァンズ，D．著，金城克哉訳（2006）「Celibacy，禁欲」イーディー，J。編『セクシュアリティ基本用語辞 典』明石書店, pp.57-58.

大川恵美（2018）「「アセクシュアル」を知ってほしい」『AERA（アエラ）』朝日新聞出版，第31巻， 58号，p.56. 釜野さおり・石田仁・岩本健良・小山泰代・千年よしみ・平森大規・藤井ひろみ・布施香奈 - 山内昌和・吉仲崇

（2019）『大阪市の働き方と暮らしの多様性と共生にかんするアンケート報告書（単純集計結果）』JSPS 科 研費16H03709「性的指向と性自認の人口学一日本に打ける研究基盤の構築」（研究代表者 釜野さおり）

http://www.ipss.go.jp/projects/j/SOGI/*20191108大阪市民調査報告書（修正 2 ).pdf（2021年 2 月25日 最終アクセス).

埼玉県（2021）『埼玉県 多様性を尊重する共生社会づくりに関する調査一報告書一』

https://www.pref.saitama.lg.jp/documents/183194/lgbtqchousahoukokusho.pdf（2021年 2 月25日最終 アクセス).

デッカー, J. S. 著, 上田勢子訳（2019）『見えない性的指向アセクシュアルのすべて——誰にも性的魅力を感 じない私たちについて』明石書店.

認定 NPO 法人虹色ダイバーシティ・国際基督教大学ジェンダー研究センター（2020）『niji VOICE 2020報告 書』https://nijibridge.jp/wp-content/uploads/2020/12/nijiVOICE2020.pdf（2021年 2 月25日最終アクセ ス).

ブレイン，J. 著，金城克哉訳（2006）「Asexuality、アセクシュアリティ、非性愛」イーディー，J. 編『セク シュアリティ基本用語辞典』明石書店, p.35.

松浦優（2020）「メランコリー的ジェンダーと強制的性愛—アセクシュアルの「抹消」に関する理論的考察」 『Gender \& Sexuality』第15号, pp.115-137.

三宅大二郎（2017）「asexual のドラマトゥルギー—AVENにおける定義の変遷に着目して」藤川信夫編『人 生の調律師たち——動的ドラマトゥルギーの展開』春風社, pp.370-408.

山本奈朱香 (2018)「恋愛感情がわからない...性的関係のぞまない「アセクシュアル」」

https://withnews.jp/article/f0181101006qq000000000000000W09t10101qq000018242A（2021年 2 月25日最 終アクセス).

吉岡真梨子（2019）「Asexual であるという自覚はいかにしてなされ自己受容されるのか？一ライフストーリー・ インタビューによる事例から」『学習開発学研究』第 12 号, pp.61-70.

American Psychiatric Association (2000) Diagnostic and Statistical Manual of Mental Disorders, 4th ed., Washington DC, American Psychiatric Publishing.

American Psychiatric Association (2013) Diagnostic and Statistical Manual of Mental Disorders, 5th ed., Washington DC, American Psychiatric Publishing.

Antonsen, A. N., Zdaniuk, B., Yule, M. and Brotto, L. A. (2020) "Ace and Aro: Understanding Differences in Romantic Attractions Among Persons Identifying as Asexual," Archives of Sexual Behavior,

Vol. 49, Issue 5, pp.1615-1630.

Baumle, A. K. ed. (2013) International Handbook on the Demography of Sexuality, Dordrecht, Springer. Bogaert, A. F. (2004) "Asexuality: Prevalence and Associated Factors in a National Probability Sample,"

The Journal of Sex Research, Vol. 41, Number 3, pp.279-287.

Bogaert, A. F. (2006) "Toward a Conceptual Understanding of Asexuality," Review of General Psychology, Vol. 10, Issue 3, pp.241-250. 
Bogaert, A. F. (2012) "Asexuality and Autochorissexualism (Identity-Less Sexuality)," Archives of Sexual Behavior, Vol. 41, Issue 6, pp.1513-1514.

Bogaert, A. F. (2013) "The Demography of Asexuality," in Baumle, A. K. ed. International Handbook on the Demography of Sexuality, Dordrecht, Springer, pp.275-288.

Bogaert, A. F. (2015) "Asexuality: What It Is and Why It Matters," The Journal of Sex Research, Vol. 52, Number 4, pp.362-379.

Brotto, L. A., Knudson, G., Inskip, J., Rhodes, K. and Erskine, Y. (2010) "Asexuality: A Mixed-Methods Approach," Archives of Sexual Behavior, Vol. 39, Issue 3, pp.599-618.

Brotto, L. A. and Yule, M. A. (2011) "Physiological and Subjective Sexual Arousal in Self-Identified Asexual Women," Archives of Sexual Behavior, Vol. 40, Issue 4, pp.699-712.

Carroll, M. (2020) "What Can Asexuality Offer Sociology? Insights from the 2017 Asexual Community Census," SocArXiv. https://doi.org/10.31235/osf.io/bh7t3 (2021年2月25日最終アクセス).

Chasin, C. D. (2011) "Theoretical Issues in the Study of Asexuality," Archives of Sexual Behavior, Vol. 40, Issue 4, pp.713-723.

Chasin, C. D. (2014) "Making Sense in and of the Asexual Community: Navigating Relationships and Identities in a Context of Resistance," Journal of Community \& Applied Social Psychology, Vol. 25, Issue 2, pp.167-180.

Chu, E. (2014) "Radical Identity Politics: Asexuality and Contemporary Articulations of Identity," in Cerankowski, K. J. and Milks, M. eds. Asexualities: Feminist and Queer Perspectives, New York, Routledge, pp.79-99.

Gazzola, S. B. and Morrison, M. A. (2011) "Asexuality: An Emergent Sexual Orientation," in Morrison, T. G., Morrison, M. A., Carrigan, M. A. and McDermott, D. T. eds. Sexual Minority Research in the New Millennium, New York, Nova Science Publisher, pp.21-44.

Greaves, L., Barlow, F. K., Huang, Y., Stronge, S., Fraser G. and Sibley, C. G. (2017) "Asexual Identity in a New Zealand National Sample: Demographics, Well-Being, and Health," Archives of Sexual Behavior, Vol. 46, Issue 8, pp.2417-2427.

Gupta, K. (2019) "Gendering Asexuality and Asexualizing Gender: A Qualitative Study Exploring the Intersections between Gender and Asexuality," Sexualities, Vol. 22, Issue 7-8, pp.1197-1216.

Hinderliter, A. (2009) "Methodological Issues for Studying Asexuality," Archives of Sexual Behavior, Vol. 38, Issue 5, pp.619-621.

Hinderliter, A. (2013) "How is Asexuality Different from Hypoactive Sexual Desire Disorder?," Psychology \& Sexuality, Vol. 4, Issue 2, pp.167-178.

Hinderliter, A. (2015) "Sexual Dysfunctions and Asexuality in DSM-5," in Demazeux, S. and Singy, P. eds. The DSM-5 in Perspective Philosophical Reflections on the Psychiatric Babel, New York, Springer, pp.125-139.

Hiramori, D. and Kamano, S. (2020a) "Understanding Sexual Orientation Identity, Sexual/Romantic Attraction, and Sexual Behavior beyond Western Societies: The Case of Japan," SocArXiv. https://doi.org/10.31235/osf.io/ds8at (2021年2月25日最終アクセス).

Hiramori, D. and Kamano, S. (2020b) "Asking about Sexual Orientation and Gender Identity in Social Surveys in Japan: Findings from the Osaka City Residents' Survey and Related Preparatory Studies," Journal of Population Problems, Vol. 76, No. 4, pp.443-466.

Kobayashi, J. (2017) "Have Japanese People Become Asexual? Love in Japan," International Journal of Japanese Sociology, Vol. 26, Issue 1, pp.13-22.

Krueger, E. A., Fish, J. N., Hammack, P. L., Lightfoot, M., Bishop, M. D. and Russell, S. T. (2020)

"Comparing National Probability and Community-Based Samples of Sexual Minority Adults:

Implications and Recommendations for Sampling and Measurement," Archives of Sexual Behavior,

Vol. 49, Issue 5, pp.1463-1475.

Mardell, A. (2016) The ABC's of LGBT+, Florida, Mango Media.

Pacho, A. (2013) "Establishing Asexual Identity: The Essential, the Imaginary, and the Collective," 
Graduate Journal of Social Science, Vol. 10, Issue 1, pp.13-35.

Poston, D. L., Jr. and Baumle, A. K. (2010) "Patterns of Asexuality in the United States," Demographic Research, Vol. 23, Article 18, pp.509-530.

Prause, N. and Graham, C. A. (2007) "Asexuality: Classification and Characterization," Archives of Sexual Behavior, Vol. 36, Issue 3, pp.341-356.

Przybylo, E. (2014) "Masculine Doubt and Sexual Wonder: Asexually-Identified Men Talk about Their (A)sexualities," in Cerankowski, K. J. and Milks, M. eds. Asexualities: Feminist and Queer Perspectives, New York, Routledge, pp.225-247.

Przybylo, E. (2016) "Introducing Asexuality, Unthinking Sex," in Fischer, N. and Seidman, S. eds. Introducing the New Sexuality Studies, 3rd Edition, New York, Routledge, pp.181-191.

Scherrer, K. S. (2008) "Coming to an Asexual Identity: Negotiating Identity, Negotiating Desire," Sexualities, Vol. 11, Issue 5, pp.621-641.

Sexual Minority Assessment Research Team (SMART) (2009) Best Practices for Asking Questions about Sexual Orientation on Surveys, Los Angeles, The Williams Institute.

Tori, B. (2018) "Gender Discrepancy in Asexual Identity: The Effect of Hegemonic Gender Norms on Asexual Identification," WWU Honors Program Senior Projects, 81, https://cedar.wwu.edu/wwu_honors/81 (2021年3月31日最終アクセス).

Vares, T. (2018) "'My [Asexuality] Is Playing Hell with My Dating Life’: Romantic Identified Asexuals Negotiate the Dating Game," Sexualities, Vol. 21, Issue 4, pp.520-536.

Weis, R., Tomaskovic-Moore, S., Bauer, C., Miller, T. L., Adroit, M., Baba, A., van der Biezen, T., Burns, R., Cotter, N., Dodson, K., G, L., Ginoza, M., Guo, Y., Hermann, L., Lee, W., McCann, S., Mellema, R., Meinhold, M., Nicholson, S., Penten, P., Trieu, T. H., Walfrand, A., Youngblom, K. and Ziebert, J. (2020) The 2017 and 2018 Asexual Community Survey Summary Report, https://asexualcensus.wordpress.com/2020/10/29/2017-2018-ace-community-survey-report (2021年2月25日最終アクセス).

Yule, M. A., Brotto, L. A. and Gorzalka, B. B. (2014) "Biological Markers of Asexuality: Handedness, Birth Order, and Finger Length Ratios in Self-Identified Asexual Men and Women," Archives of Sexual Behavior, Vol. 43, Issue 2, pp.299-310.

Zheng, L. and Su, Y. (2018) "Patterns of Asexuality in China: Sexual Activity, Sexual and Romantic Attraction, and Sexual Desire," Archives of Sexual Behavior, Vol. 47, Issue 4, pp.1265-1276. 


\title{
Demographic Diversity of the Aromantic/Asexual Spectrum in Japan: Findings from the 2020 Aro/Ace Survey
}

\author{
MIYAKE Daijiro and HIRAMORI Daiki
}

In Western countries, studies using representative surveys and community surveys have begun to reveal the size and the diversity of the asexual population. On the other hand, in Japan, there are only a few studies using representative surveys, and the detailed realities of the asexual population are yet to be explored. This article analyzed a web survey "Aromantic/Asexual Spectrum Survey 2020," conducted by the Aro/Ace Survey Executive Committee. Most of the respondents tended to be cisgender women, young people, and residents of the southern Kanto region. Many identified as aromantic and asexual, but some identified as other aro/ace identities. We also conducted an analysis on "nonsexual," an identity category unique to Japan. While masturbation and sex drives were found in a certain number of asexual respondents, the proportion of those who would like to have sexual contact with others was particularly low among asexual respondents. We conclude that sexual contact with others has important implications for self-identification.

Keywords: asexual, aromantic, LGBT, sexual and gender minorities, sexual orientation and romantic orientation 